\title{
OXFORD AND THE FRANKS REPORT
}

T 'HE University of Oxford will now know the worst. The Report of the Commission of Inquiry under Lord Franks has now been published (May 12, 1966, Clarendon Press). Externally, the chief consequences will be new policies on the admission of undergraduates, on the balance between undergraduates and graduates and between the arts and the sciences. For the rest, the report recommends important changes in the administration of the university including a proposal to centralize the machinery for making decisions without losing the appearance, and some of the reality, of democracy; the taxation of richer colleges for the benefit of the poorer, and the re-organization of academic life in such a way that the separation between the colleges and the university is less pronounced than it has been in recent centuries. It is also proposed that All Souls should have three years "to set its house in order", and in particular to decide how to spend its excess investment revenue. Apart from being a vehicle for specific proposals for change, the Franks Report is also a fascinating and frequently an eloquent exercise in the sociology of a university which is, for better and worse, without compare.

The Franks Commission was created by Oxford in February 1964, after the criticisms of Oxford which appeared in the Robbins Report. The terms of reference were wide, and the Commission was required to assess "the part which Oxford plays now and should play" in the future in the system of higher education in the United Kingdom, having regard to its position as both a national and an international university". Among the questions specifically referred to were the administration of the University and the arrangements for the appointment of a Vice-chancellor, the relationship between the University and outside bodies including those from which public funds are obtainable, the relationship between the autonomous university and the substantially autonomous colleges, and matters of finance, staffing, curriculum, selection, examination and postgraduate teaching. The Commission collected evidence throughout 1964, and its work included special surveys, based on questionnaires, of matters such as the academic needs of undergraduates and the work-load of the academic staff. The members were Lord Franks, Sir Lindor Brown, Mrs. J. Floud, Sir Robert Hall, Miss M. G. Ord, Mr. M. Shock and Mr. J. Steven Watson.

The Commission readily accepts a good many of the criticisms made of Oxford in the Robbins Report and elsewhere. Thus it accepts that "an effective administrative system which combines democracy with decision is the first need of Oxford. Unless this is secured, other reforms cannot be undertaken with real hope of success". It accepts "that the mists through which Oxford permits itself to be seen can obscure much more than its statistics". The result, the Commission says, is the prevalence of misconceptions which "arise from Oxford's failure to take the trouble to explain itself". At the outset, the Commission also notes the criticisms that "Oxford is a privileged place", that its academic efficiency is low, that the university as a whole pays too little attention to postgraduate teaching and that the college system, which emphasizes the importance of undergraduate work, exacerbates the neglect of research.

\section{Admissions to Oxford}

The Franks Commission says that the problem of selecting undergraduates has been complicated since the end of the Second World War by the great increase in the number of young people seeking entrance to universities and by the wish of schools other than independent and direct grant schools (which are partly dependent on public funds but independently governed) to prepare students for universities. The existing procedure for selecting candidates, based on an entrance examination administered by the colleges, is said to be valuable in itself but to be attended by undesirable consequences. For one thing, the entrance examination supposes that candidates will have spent more than two years in the sixth-form of a British school and will have been provided with knowledge extending well beyond the Advancedlevel examination taken by all senior school leavers.

Though the Commission does not accept that Oxford is biased against pupils from maintained schools, and though it can point with satisfaction to the steady increase in the proportion of those admitted to Oxford from maintained schools (19 per cent of male entries in 1938 and 40 per cent in 1965), the Commission does accept that "Oxford is not yet receiving applications from candidates coming. from these schools on the scale that the number of prospective university entrants would warrant". The result, says the Report, is that Oxford is impoverished in the quality of its students and their diversity, and that it is exposed to the "suspicion of privilege and social injustice". This difficulty" is likely to be increased by the growth of comprehensive schools. "The low application rate from the maintained schools is evidence that Oxford is lacking officiency as it fishes for promising talent in the national pool: from this point of view the present entrance examination is neither academically successful nor socially just."

What is to be done? The Franks Commission argues that it will be impracticable and undesirable for Oxford to maintain a selection system independent of that used by other British universities, espocially as its proportion of all university entrants in Britain declines from the present 7 per cent. But A-level examinations are not a good basis for selection, because they are not designed for university entrance, because university selectors do not play a part in their design and because A-level marks "are not necessarily a good guide to promise in university work". In the long run, the Commission holds, there will have to be a nation-wide system for selecting undergraduates for entry to British universities, but it also says it would not help if Oxford were to throw in its lot, with the other universities in the immediate future, and were to rely on the machinery of the Universities Central Council on Admissions (UCCA), because that would "increase the already undesirable pressure which university requirements at A-level puts on the work of the schools". Thus it is that the Franks Commission recommends "that the long-term solution lies in the adoption of a new common admissions system by all universities, and we recommend that Oxford should work towards the initiation of plans for the reform of the admissions system on a national scale. What is wanted is a completely fresh look at the problem of university selection. We think that Oxford is well placed to take an initiative in this matter".

Recognizing that all this cannot come about overnight, the Franks Commission has proposed an interim revision of the Oxford entrance procedure, principally to meet the fear that the university is not sufficiently accessible to pupils who do not spend a third yoar in the sixth form at their secondary schools. Briefly, it is proposed that there should be two parallel entrance examinations, one for candidates who have spent more than two years in the sixth form, and another for those who offer themselves a year earlier in the school chronology, and who are sufficiently mature (17.5 years in the December of the academic 
year in which entry is sought). The Franks Commission reckons that some 10 per cent of the present intake of undergraduates at Oxford would at present qualify under such a procedure, and it suggests that the university as a whole should aim at selecting some 20 per cent of its intake by means of an examination taken before A-level. (The Commission sets its face against a fixed quota.)

Closed scholarships should be abolished, and oponscholar. ships and exhibitions reduced in number so that no more than 10 per cent of the undergraduate population of any college hold scholarships, and in such a way that the valuo of all awards to undergraduates should be worth $£ 50$ a year, and should be dependent on evidence of satisfactory work year by year.

\section{Modest Growth}

If the Commission has its way", the undergraduate population will grow modestly in the years immediately ahead, and the postgraduate population will grow much more quickly. Table 1 surmmarizes recent experience of the growth of the student population and the predic. tions of the Franks Commission.

\begin{tabular}{|c|c|c|c|c|}
\hline \multicolumn{5}{|c|}{ Table 1} \\
\hline & $1928-29$ & $1948-49$ & $1965-66$ & 1980-85 (est.) \\
\hline $\begin{array}{l}\text { Undergraduates } \\
\text { Arts, etc. } \\
\text { Science }\end{array}$ & $\begin{array}{r}3,402 \\
714\end{array}$ & $\begin{array}{l}4,679 \\
1,480\end{array}$ & $\begin{array}{l}5,080 \\
2,518\end{array}$ & $\begin{array}{l}5,000-5,500 \\
3,250-3,750\end{array}$ \\
\hline $\begin{array}{l}\text { Graduates } \\
\text { Arts, etc. } \\
\text { Science }\end{array}$ & $\begin{array}{r}309 \\
48\end{array}$ & $\begin{array}{l}717 \\
354\end{array}$ & $\begin{array}{r}1,235 \\
991\end{array}$ & $\begin{array}{l}1,750-2,250 \\
2,000-2,500\end{array}$ \\
\hline All students & $4,559^{*}$ & $7,294^{*}$ & 9,824 & 13,000 (est.) \\
\hline
\end{tabular}

Predictions about the future size of the postgraduate population are based partly on the recognition of a growing need of postgraduate teaching and partly on the arguments of faculties at Oxford which have provided the Commission with estimates of their own futures. Thus the Commission recommends a growth of the postgraduate population from 23 per cent at present to at least 30 per cont.

The comparatively small increase in the total size of the university is held, in the Report, to be necessary if the collegiate structure of the university, and the advantages thereof, are to be retained. A college, the argument goes, should not be so big that "no one person can hope to know all the members", which is said to be roughly equivalent to the rule of thumb that no college should have more than 500 members, students and senior member's. The Franks Commission also holds that the university would lose its cohesion if the number of colleges were to grow without restraint.

'The Commission is far less specific about the directions in which such expansion as it recommends should take place. It diroets attention to the plans for expansion which already exist in the fields of science and technology, but points out that ehanges in the numbers of students following courses of different kinds have come about as a result of the policies of individual colleges on the admission of undergraduates. Obviously the Franks Commission is anxious that there should in future be a better co-ordination of these separate tendencies, apparently through the Council of the Colleges, the formation of which is intended to serve tho whole causo of co-ordinating college policy.

\section{Conditions of Work}

The Oxford tutorial system is tho most surprising of the many aspects of academic life at Oxford that the Franks Commission would like to soe changed. Sensibly, however, the Report points out that no system of tutorials can at present cover the whole of an undergraduate syllabus without an oxcessive expenditure of time and effort. It also accepts a great deal of the argument from university teachers to the effect that present concorn for the tutorial system entails too great a burden on the academic staff, and recommends that no student should be expected to write more than one tutorial essay a week during term (though he may attend more than one tutorial in the company of others).

The proposals on the conditions of service for academic staff may do much --if they are eventually accepted by the university - to simplify the movement of acadomies out of and into Oxford. The complications of the present system under which teachers may be appointed either by colleges or by the university, though sometimes by both, are to be removed by a common system of appointment under which university and colleges share responsibility. The arrangoments proposod would creato the category of "Fellow-lecturer", appointed jointly by the university and by one of the colleges, and required to teach for "up to fourteen hours" a week. Some Follow. lecturers would owo their first allegiance to the university, and others to a particular college, but none would be ontirely in one camp. Stipends would vary a little--.. Franks thinks not much-aceording to the college. University readers would increasingly be freed from undergraduate teaching to spend time on postgraduate instruction and supervision, and should have salarios of up to $£ 3,250$ a year, with an extra $£ 400$ for those retaining the teaching duties in colleges. The Franks Commission would also create more teaching posts at the professorial level, and though there is no suggestion of abandoning

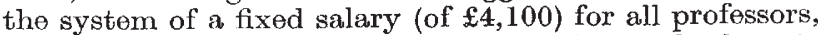
it is planned that a professor who is also head of a departmont can retain his special responsibility allowance without having to do the administration that would normally be involved.

A measure of the extent to which Oxford teachers are said to be overburdened with teaching at present is the calculation of the Commission that the university would have to (and should) recruit a further 182 teachers to bring the size of its teaching staff to the level used as a national standard by the Univorsity Grants Commission. Further regularities should flow from the set of detailed proposals that would ensure that college Fellows are equitably and fully charged for the benefits in kind which attachment to a college may somotimes bring.

For the rest, the Report of the Commission makes several recommendations about the improvement of the co-ordination of teaching programmes, for postgraduates and undergraduates alike. Examinations are to be coordinated, and continuity preserved from one year to another; arrangements made to see that all university posts should carry with them the automatic right to an M.A. degree and the right that stems from it to take part in the government of the university; the Queen will be asked to forgo her prerogative to appoint the Regius professors at Oxford (with the exception of the canons of Christ Church); and all colleges will be expected to obtain university consent before making senior resoarch appointments.

The Report is scornful of All Souls and of the suecessive atternpts of that college, spread out over the years since the Royal Commission on Oxford in 1922, to spend the whole of its investment income now amounting to close on $£ 250,000$ a year. The report suggests that All Souls should aim to spond at least $£ 100,000$ on academic activities of its own, and that tho college should present a plan to this end to the Univorsity within three years.

On general administration and finance, the Report suggests the creation of networks of interlocking committees for general and academic purposes. Within them, the Vice-Chancellor would becomo more powerful than at present, though it is not proposed to appoint permanent Vice-Chancellors at Oxford but merely to extend the term of office from two years to four. Arrangements are to be made for taxing the richer collegos to support the poorer, which will make it easier for the latter to take on their full share of postgraduate students. 